\title{
Articles
}

\section{NCAA Scholarship Limits and Competitive Balance in College Football}

\author{
DANIEL SUTTER \\ University of Oklahoma \\ STEPHEN WINKLER \\ The Oklahoma Publishing Company
}

\begin{abstract}
Conventional wisdom holds that parity has increased in college football in recent decades due largely to limits on the number of scholarships teams can offer. The authors find that competitive balance has not increased in college football since the end of World War II, and they find mixed evidence of scholarship limits' effect on a range of measures of parity, including the standard deviation of winning percentages and Associated Press rankings. They also examine the 1991 NCAA roll-call vote to reduce the scholarship limit and find some evidence that stronger teams were more likely to vote for the lower limit.
\end{abstract}

Keywords: college football, competitive balance, Coase Theorem

$T$ he end of summer heralds the start of the college football season in America, a tradition that goes back more than a century. Although hope always springs eternal for sports fans, experts particularly remark about the degree of parity in college football today compared to the dominance of the sport by a handful of powers in decades past. Many commentators attribute parity to NCAA scholarship limits. The NCAA in 1977 limited Division I-A schools to 95 scholarships and then in 1992 reduced the limit to 85 and no more than 25 in any one year. Scholarship limits

\footnotetext{
AUTHORS' NOTE: We would like to thank Tony Caporale, Joe McGarrity, Bob Reed, Gerald Scully, Bob Tollison, and two referees for comments on an earlier draft. Ellen Summers, archivist for the NCAA, provided us with the roll-call vote on scholarship limits and identified teams on football probation. James and Sherri Howell, who maintain a database on college football history, provided us with data on the number of major teams prior to Division I-A designation and the average number of games played.

JOURNAL OF SPORTS ECONOMICS, Vol. 4 No. 1, February 2003 3-18 DOI: $10.1177 / 1527002502239655$

(C) 2003 Sage Publications
} 
prevent top programs from stockpiling players; talented players not receiving a scholarship from a power might instead sign with a weaker team. ${ }^{1}$

The conventional wisdom takes increased parity as a stylized fact and assumes scholarship limits could not reduce competitive balance. Yet scholarship limits could prevent a football outsider from breaking into the elite. Traditional powers possess numerous advantages in recruiting high school players, including large fan bases, the expectation of future success, and extra television appearances. A school seeking to break into the elite might need to spend more for facilities, coaches, and players to offset the established powers' advantages. Fleisher, Goff, and Tollison (1992) and Eckard (1998) argue that the NCAA protects the traditional powers; scholarship limits could be one means of entrenching football incumbents.

We explore measures of parity in college football since World War II and the effect of scholarship limits on competitive balance. We also include other changes in the rules of college football, like the 1984 Supreme Court ruling against the NCAA's control over television contracts in National Collegiate Athletic Association v. Board of Regents of the University of Oklahoma et al. and changes in freshmen eligibility. We employ measures of parity based on the final Associated Press (AP) rankings, the conference champions, the average margin of victory, and the standard deviation of winning percentages of major college teams.

The article proceeds as follows. The first section discusses goals the NCAA may pursue in managing the college football cartel and the role of scholarship limits. We contrast three hypothesized roles for scholarship limits: (a) to limit the talent of top programs and level the playing field, (b) to protect the existing powers by restricting the efforts of outsiders to break into the football elite, and (c) to limit the costs of college football. We examine two types of evidence to discriminate between these rationales for scholarship limits: the effect of limits on parity and analysis of the NCAA vote to lower the scholarship limit to 85 . The second section describes the measures of parity used in this study. The third section presents evidence on the effect of limits on competitive balance. Contrary to perception, parity has not increased in college football since 1977; indeed, several measures indicate a decrease in parity. We also present econometric estimates of a model of competitive balance in football that includes a time trend and other football policy changes. The regressions find mixed evidence of the effect of scholarship limits on parity. Consequently, the fourth section presents analysis of the NCAA roll-call vote to reduce the scholarship limit, which provides more direct evidence on the possible motive for scholarship limits. Recent (but not historical) success significantly determinant of votes, which suggests that scholarship limits were intended to either entrench incumbents or not affect competitive balance. Finally, we offer a brief conclusion.

\section{SCHOLARSHIP LIMITS AND PARITY}

The original purpose of the NCAA was to limit football injuries (Byers, 1995; Fleisher et al., 1992), but groups formed for one collective purpose often pursue 
other goals as a by-product (Olson, 1965). Economists generally concur that today the NCAA acts as a cartel in maintaining the amateur status of collegiate athletesthat is, keeping the salaries of student-athletes set to zero (Becker, 1987; Fizel \& Bennett, 2000; Fleisher et al., 1992). The NCAA has been called the "best monopoly in America" (Barro, 1996, pp. 127-131). The NCAA is a nonprofit organization and so may not pursue profit maximization in the conventional manner. The cartel may pursue other goals at the expense of profit and take the profits from amateur status in nonpecuniary forms like perks, publicity, and success on the football field. Member schools - and their students, fans, and alumni-value winning football games. Success in football may generate several tangible benefits for universities: increased revenue through ticket sales and attracting extra students (Borland, Goff, \& Pulsinelli, 1992); larger gifts from alumni, both for athletic programs and the university (McCormick \& Tinsley, 1990); and a larger applicant pool, which allows higher admission standards (McCormick \& Tinsley, 1987).

Would the NCAA prefer more or less parity in college football? The answer depends on the breadth of the membership represented by the organization. An NCAA managing football in the interest of all its members (or at least Division I-A football schools) would choose policies to maximize the value of the product; thus, the NCAA would seek to increase fan interest and maximize revenues from attendance and the value of television broadcast rights (DeBrock \& Hendricks, 1997). Greater parity might be a means of achieving this goal. But the NCAA may represent a narrower coalition, say, traditional football powers against would-be challengers. A narrow coalition NCAA would impose rules benefiting the traditional powers. Several policies raise the costs of entrants and are consistent with a "narrow cartel" view. The NCAA targets teams experiencing an improvement in win-loss records for investigation for rules violations (Fleisher, Goff, Shughart, \& Tollison, 1988) and requires Division I-A football participants to field a minimum number of varsity teams and meet minimum stadium and attendance requirements (Fizel \& Bennett, 2001). Eckard (1998) finds that creation of a punishment mechanism for the NCAA in 1952 reduced competitive balance, consistent with the narrow cartel thesis.

Two models could be applied to examine the expected impact of scholarship limits on competitive balance. Signing high school players could be viewed as an investment under uncertainty. Players are still developing physically at this age, and competition in high school is not homogeneous. In addition, commitment and willingness to work hard are difficult to observe yet affect transformation of a player's inherent ability into football skills. And exogenous factors like injuries can unexpectedly end a player's career or slow his development. Each scholarship allows a team to take a draw from the urn of high school talent. Strong teams historically get the best high school prospects, with weaker schools signing players later. More draws generate a higher probability of developing enough quality players (taking in-season injuries into account) to field a successful team each year. Without limits, a school will offer scholarships until marginal benefit equals marginal cost, keeping 
in mind that the benefit could include stockpiling promising players to deny their services to rival teams. ${ }^{2}$ Binding limits increase top schools' vulnerability to injuries and possibly strengthen weaker teams, as players who would sign with elite programs are forced to take scholarships at other schools. These arguments support the conventional wisdom that limits hurt historically strong schools and produce greater parity (Byers, 1995, p. 228).

Scholarship limits, though, might also limit the number of players signed by and thus hurt weaker teams. In other words, the conventional wisdom focuses on the partial equilibrium effect of limits on top programs. Weaker programs face a riskier investment decision because they do not sign the best high school players and, thus, need to sign more players per position in hopes of developing one quality starter. Additionally, scholarships may not be necessary to attract high school players to a college program, because some walk on (enroll in classes without a scholarship) and then try out for the football team. In choosing among colleges, a player will consider the quality of education and the prospect of success during a player's career-winning seasons, television appearances, bowl games, conference championships, and so on. Traditional powers offer the likelihood of winning, which a new program or traditional also-ran cannot. A school seeking to upgrade its football program could raise financial resources to fund scholarships (and build facilities and hire coaches) but can establish a winning tradition only through winning. Scholarship limits might force all teams to rely on walk-ons to supplement scholarship recruits, and traditional powers can offer walk-ons more intangible benefits than can also-rans. ${ }^{3}$ The current scholarship limits also prevent a team from awarding more than 25 scholarships in a year. A traditionally weak program might use all or most of its scholarships on one large recruiting class in hopes of success 4 or 5 years later with an experienced team, success that could change the attitudes of the media and high school players toward the program and improve its long-term prospects for success. ${ }^{4}$

The invariance proposition of the Coase theorem (Coase, 1960) provides another model to apply to scholarship limits. The invariance proposition holds that with tradable property rights and zero transactions costs, changes in institutional rules should not affect the allocation of resources. The Coase theorem has been widely applied to the market for professional baseball players (Daly \& Moore, 1981; Hylan, Lage, \& Treglia, 1996) and predicts that the introduction of free agency should not alter the distribution of players. Consequently, if transactions costs are low, free agency should not affect competitive balance either, as Butler (1995) does indeed find. The invariance proposition suggests that if transactions costs are low, scholarship limits should not affect competitive balance in college football. Transactions costs, however, are not zero in the market for college football players; specifically, schools are limited in their ability to make cash payments to players. Scholarship limits raise transactions costs, at least marginally, and thus might affect parity by reallocating some players to programs where they produce lower value. But whether the highest-valued users of the players in question are tra- 
ditional powers or weaker schools is theoretically ambiguous (Daly \& Moore, 1981). ${ }^{5}$ Again, the theoretical impact of limit is ambiguous.

A way of viewing scholarship limits is as a means to control the cost of college football and prevent dissipation of the rents created by the amateur status of college athletes. The NCAA prevents salary competition for athletes, but even successful cartels tend to dissipate the consequent rents through nonprice competition. Success in football is a positional good, and cartel members might be particularly vulnerable to dissipation of rents in this fashion. Frank and Cook (1995), in fact, praise NCAA scholarship limits as a successful cooperative agreement to prevent a costly positional arms race. An equal scholarship limit for all schools may have no effect on competitive balance; competitive balance might be the same if each team gave out 125 scholarships instead of the current limit of $85 .{ }^{6}$ Alternatively, limits may have some effect on competitive balance, which cartel members may accept because of the cost savings.

\section{TRENDS IN PARITY}

Parity means greater competitive balance. In college football, however, parity could have as many as three meanings. First, it could refer to balance within games. Parity in this case would mean more competitive games-for instance, a closer final score and more lead changes. Second, parity could refer to balance within seasons. Here, parity means a smaller difference in winning percentages between the top and bottom of the standings, with teams on the bottom at least occasionally defeating the teams on top. Third, parity could refer to balance across seasons, with different teams winning bowl games and conference titles from year to year. Parity could increase by one measure with no change in another measure. In the absence of a consensus measure of parity, we employ several measures based on the final margin of games, the winning percentages of all teams, AP final rankings for each season, and conference champions. The source for all the college football records used in this study is Stassen (2001).

Our first measure of parity uses the margin of difference in major college football games, a measure of parity within games. MARGIN is the difference between the average score of the winning teams in a year and the average score of losing teams. A smaller value of this variable indicates greater parity, although differences in scheduling implies that MARGIN may not be a reliable measure of balance over time.

Our second measure of parity uses the theoretical standard deviation and measures balance across games within a season. The theoretical standard deviation, introduced by Scully (1989), equals $.5 / g^{.5}$, where $g$ is the number of games played in a season. We calculate the actual standard deviation of winning percentages of all Division I-A (or Division I-A equivalent) schools in a given year. Our parity variable is RATIO, the actual standard deviation divided by the theoretical standard deviation, a measure employed by Bennett and Fizel (1995). Total parity would 
produce a value of 1.0 for this variable, whereas a larger value indicates less balance.

We use three season-to-season measures employed by Eckard (1998) and based on the final AP college football writers' rankings. Our measures include poll entrants/reentrants (teams appearing in the rankings after not appearing in any of the 5 previous years), the total number of different teams appearing in the rankings over a given number of years, and a Herfindahl-Hirschman Index (HHI) of concentration of poll appearances. We construct measures using both the entire Top 20 and just the Top 10-the latter measures the very elite of college football, which might correspond with the definition of success for fans and teams. More entrants/ reentrants, more total teams appearing in the rankings, and a smaller HHI score indicate greater parity.

We construct these three competitive balance measures using conference champions. Conference champions provide an objective measure of success, in contrast to the possibly subjective evaluations of sports writers in the AP rankings; also, many teams and fans set conference titles as a season goal. We construct the above described entrant/reentrant, total champions, and champion HHI for six major conferences: the Atlantic Coast; Big 10; Big 8/12; Southeastern; Pacific 8/10; and Southwest, replaced in the 1990s by the Big East. ${ }^{7}$

\section{SCHOLARSHIP LIMITS AND PARITY}

We examine college football since the end of World War II, the years 1946 through $2000{ }^{8}$ Our primary interest is the effect of scholarship limits on parity, and the 95-scholarship limit was first imposed in 1977. We begin with a comparison of competitive balance in college football before and after imposition of scholarship limits. To avoid complications with reversion to mean, we follow Eckard (1998) and compare time periods of equal length before and after. Allowing 5 years following first implementation of limits for transition effects, this provides 20 years, 1982 to 2001, of play under scholarship limits. Our prelimit period, then, is 1957 to 1976. Our pre-scholarship-limit comparison period falls within the era of NCAA enforcement of eligibility, which began in 1952.

Table 1 presents our 11 measures of competitive balance for the 1957 to 1976 and 1982 to 2001 periods. $^{9}$ The MARGIN, RATIO, and ENTRANT variables are the means of the annual values of these variables for each 20-year period. Calculation of the total teams and HHI variables use the number of appearances or titles by each school over the 20-year period. The evidence on the effect of scholarship limits is mixed. Competitive balance is lower in the period of scholarship limitation with MARGIN and RATIO, and these differences are significant at the .01 level. The measures based on the AP Top 20 also all indicate reduced parity. By contrast, the measures based on the AP Top 10 indicate greater parity during the period of scholarship limitation. The measures based on conference champions are mixed in direction but are all very small in magnitude, which suggests no systematic effect of 
TABLE 1: Comparison of Parity Measures Before and After Scholarship Limits

\begin{tabular}{lcc}
\hline \hline Measure & $1957-1976$ & $1982-2001$ \\
\hline MARGIN & 16.24 & 17.19 \\
RATIO & 1.41 & 1.59 \\
Top 20 & & \\
$\quad$ Entrants (per year) & 3.70 & 3.35 \\
Total teams & 79 & 68 \\
Herfindahl-Hirschman Index (HHI) & 224.8 & 244.3 \\
Top 10 & & \\
Entrants (per year) & 2.05 & 2.70 \\
Total teams & 47 & 52 \\
HHI & 377.5 & 352.0 \\
Conference champs & & \\
$\quad$ Entrants (per year) & 2.05 & 1.95 \\
Total teams & 36 & 35 \\
HHI & 510.2 & 492.1 \\
\hline
\end{tabular}

scholarship limits on competitive balance. The differences in entrants for both AP totals and conference champions are not significant.

We turn next to time series measures of competitive balance over the entire postwar period. Here we calculate team totals and HHI over 5-year periods. For example, the 1950 values of these variables are based on the five seasons from 1946 to 1950. ${ }^{10}$ Figures 1, 2, and 3 display the time series of eight of our competitive balance variables; Figure 1 displays RATIO and MARGIN, Figure 2 displays the total number of teams in the Top 20 and Top 10 and that are conference champions; and Figure 3 displays the HHI for the Top 20, Top 10, and conference champions. MARGIN trends downward from about 19 to its low of 14.14 in 1964, then spikes up sharply over the next several years and has been relatively steady since 1975, first around 16.5 and then around 17.5 for the past decade. RATIO remains relatively steady at values less than 1.50 for the first 30 years of our sample, then rises to values generally in excess of 1.50 over the past 25 years, with no discernable trends within these ranges. The total teams counts begin at historically high levels in the early 1950s, then remain steady until taking sharp declines in the early 1970s and then returning to approximately the same levels by the late 1980s as in the 1960s. The HHIs all follow a similar pattern of remaining steady at low levels throughout the 1950s and 1960s and then reaching their postwar peaks in the early 1970s, followed by declines to relatively steady states, although at higher levels of concentration generally than prior to the late 1960s.

Comparison of the prelimitation and postlimitation periods does not control for other changes possibly affecting competitive balance in college football. Scholarship limits might well have increased parity in college football, ceteris paribus, but 


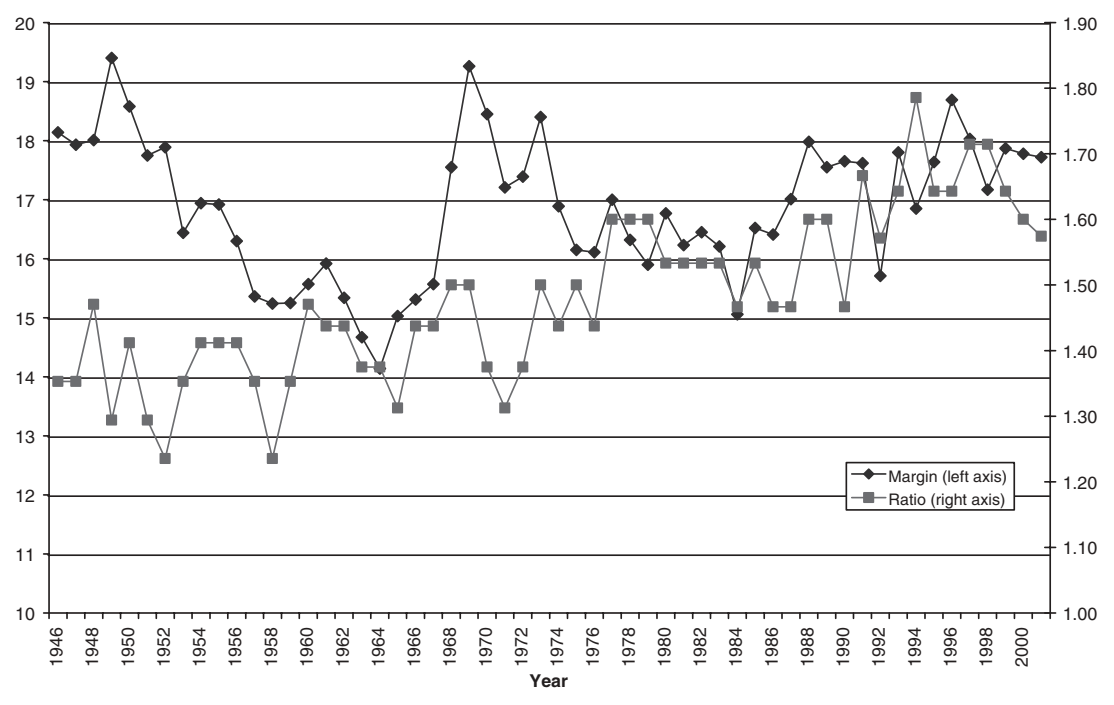

Figure 1: Time Trend for MARGIN and RATIO

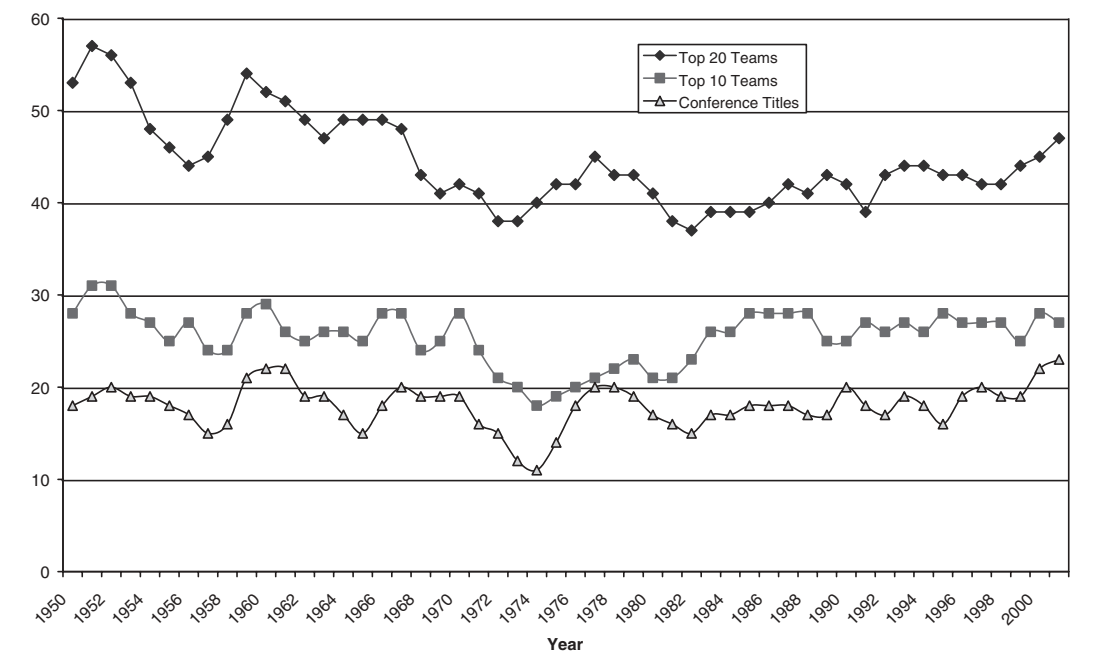

Figure 2: Number of Teams in Associated Press Rankings and Winning Conference Titles Over 5-Year Periods

other rule changes might have led to less balance, offsetting the effect of limits. Or scholarship limits might have canceled a time trend toward less balance. To exam- 


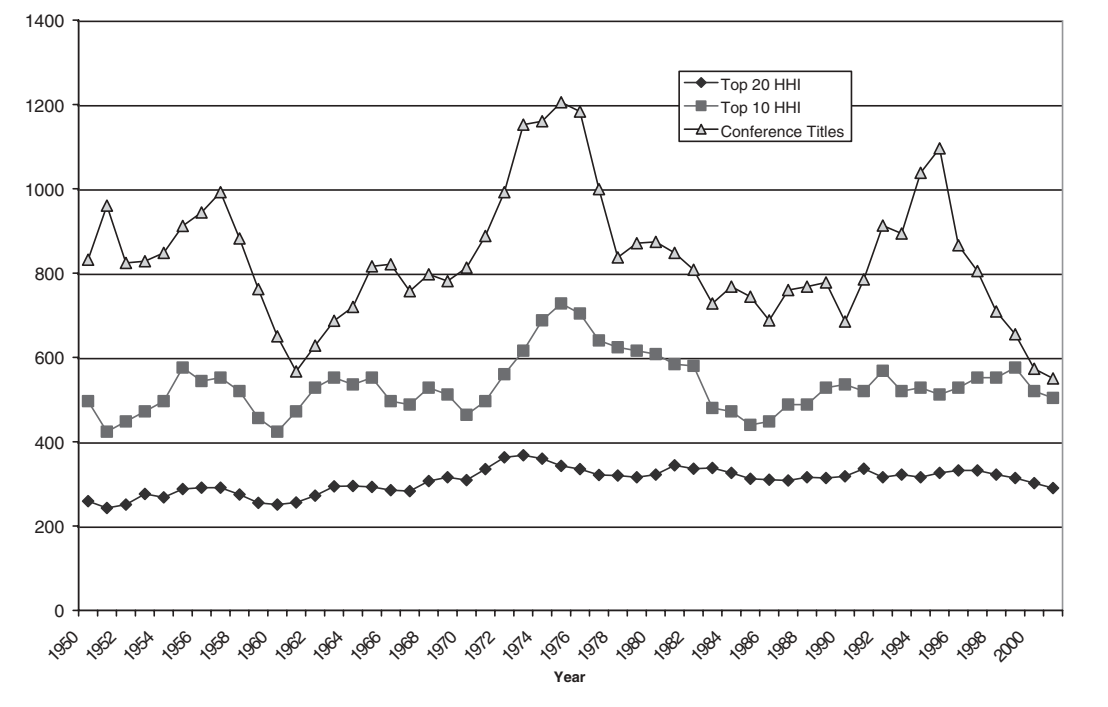

Figure 3: Time Trend for 5-Year Herfindahl-Hirschman Indexes (HHIs)

ine the marginal effect of limits, we estimate the following model using our various measures of parity as dependent variables:

$$
\begin{aligned}
& \text { Parity }=\beta_{0}+\beta_{1} * \text { S95 }+\beta_{2} * \text { S85 }+\beta_{3} * \text { TEAMS }_{t} \\
& +\beta_{4}{ }^{*} \text { FRESHMAN }_{t}+\beta_{5} * \mathrm{TV}_{t}+\beta_{6} * \mathrm{TIME}_{t}+\varepsilon_{t} \text {. }
\end{aligned}
$$

S95 and S85 are dummy variables that equal one for the years in which the 95scholarship (1977-1991) and 85-scholarship (1992-2001) limits were in effect. TEAMS is the number of teams competing in Division I-A or the estimated equivalent level of play prior to the creation of Division I-A in 1978; the conference title regressions use the number of teams in the relevant conferences. An increase in the number of teams should produce more total teams appearing in the AP rankings or winning conference titles over a given period and lower HHI values. FRESHMAN is a dummy variable that equals one for years in which freshmen were eligible to play major college football, 1972-2001. The impact of freshman eligibility is ambiguous. Extra eligibility increases the impact of the best players, and the best players tend to play for the top teams, which suggests a decrease in parity. But top teams also have greater depth and may not need to play freshmen. TV is a dummy variable that equals one for the years following the Supreme Court's ruling eliminating the NCAA's control over college football contracts (1984-2001). The NCAA television contract limited the number of appearances by top teams and shared the revenue. Elimination of these provisions allowed premier teams and 
conferences to negotiate their own television deals and keep more of the revenue, which should lead to less parity. Bennett and Fizel (1995) and Eckard (1998), however, found no evidence that the television ruling reduced balance. TIME is a time trend and equals the current year minus 1945. Social changes like greater mobility and declining travel costs could lead to greater or lesser parity over time absent rule changes, and the time trend controls for any such effects. ${ }^{11}$

Table 2 presents our estimates of the model in Equation 1. We employ CochraneOrcutt estimation to correct for autocorrelation detected in the original estimates. We first consider the scholarship limitation variables. In evaluating the impact of limits, we especially consider whether the two scholarship variables affect parity in the same direction and, if so, whether S85 has a larger quantitative impact than S95. Scholarship limits reduce within season parity as measured by RATIO. The coefficients for S95 and S85 are both significantly positive in this case, and the point estimate for S85 is almost twice as large as that for S95. S85 is significant and S95 insignificant three times, for total Top-20 teams, Top-20 HHI, and total Top-10 teams; and in each case, scholarship limits increase parity. Also, in these cases, the point estimate of S95 also indicates greater parity, is smaller than the estimate of $\mathrm{S} 85$, and is close to statistical significance. S95 is significant and indicates greater parity for conference HHI, whereas S85 is insignificant with a positive point estimate in this case, which is implausible if scholarship limits produce greater parity. In the other three cases, both the scholarship limit variables are insignificant. Our results indicate a complicated relationship between scholarship limits and competitive balance, and that the effect may be different for within- and across-season measures.

The most consistently significant control variable is FRESHMAN, which is significant in five cases (all across-year measures of parity), and in each case, freshman eligibility reduced competitive balance. Allowing the very best players an extra year of eligibility has benefited the strongest teams. TIME is significant three times (in the same cases where S85 is significant and S95 insignificant) and in each case indicates a trend toward less parity over time, consistent with greater concentration. The time trend obscures the effect of scholarship limits in the comparisons in Table 1. TEAMS was significant twice, for both the conference champion measures, which is not surprising given that there are more than 100 Division I-A football teams but only about 50 in the major conferences. TV is significant only once, for total Top-10 teams, and in this case, the estimate indicates greater parity. The general insignificance of TV is consistent with the results of Bennett and Fizel (1995) and Eckard (1998).

\section{ANALYSIS OF THE NCAA VOTE}

George Stigler (1975) argued that the intent of policies should be divined from their actual effects. Stigler's dictum in this case would suggest that scholarship limits were adopted to protect against dissipation of cartel rents. Inferring intent from 
TABLE 2: Regression Analysis of Determinants of Parity

\begin{tabular}{|c|c|c|c|c|c|c|c|c|}
\hline & \multicolumn{8}{|c|}{ Dependent Variable } \\
\hline & MARGIN & RATIO & Top-20 Teams & Top-20 HHI & Top-10 Teams & Top-10 HHI & Conference Teams & Conference HHI \\
\hline S95 & $\begin{array}{c}0.956 \\
(1.12)\end{array}$ & $\begin{array}{c}0.116^{*} \\
(1.82)\end{array}$ & $\begin{array}{c}3.42 \\
(1.61)\end{array}$ & $\begin{array}{c}-18.2 \\
(1.52)\end{array}$ & $\begin{array}{c}2.47 \\
(1.49)\end{array}$ & $\begin{array}{c}-60.3 \\
(1.59)\end{array}$ & $\begin{array}{c}2.06 \\
(1.35)\end{array}$ & $\begin{array}{l}-171^{*} \\
(2.41)\end{array}$ \\
\hline S85 & $\begin{array}{c}-0.462 \\
(0.38)\end{array}$ & $\begin{array}{l}0.197 * \\
(2.99)\end{array}$ & $\begin{array}{l}8.50^{*} \\
(2.83)\end{array}$ & $\begin{array}{c}-4.24 * \\
(2.50)\end{array}$ & $\begin{array}{l}3.82^{*} \\
(2.15)\end{array}$ & $\begin{array}{c}-36.5 \\
(0.69)\end{array}$ & $\begin{array}{r}0.959 \\
(0.39)\end{array}$ & $\begin{array}{l}23.6 \\
(0.23)\end{array}$ \\
\hline TEAMS & $\begin{array}{l}0.0500 \\
(1.54)\end{array}$ & $\begin{array}{l}0.00092 \\
(0.39)\end{array}$ & $\begin{array}{l}0.0627 \\
(0.78)\end{array}$ & $\begin{array}{l}0.0876 \\
(0.19)\end{array}$ & $\begin{array}{c}-0.0474 \\
(0.78)\end{array}$ & $\begin{array}{c}0.718 \\
(0.50)\end{array}$ & $\begin{array}{l}0.640^{*} \\
(2.13)\end{array}$ & $\begin{array}{r}-59.1 * \\
(4.25)\end{array}$ \\
\hline FRESHMAN & $\begin{array}{l}0.0621 \\
(0.07)\end{array}$ & $\begin{array}{l}0.0244 \\
(0.54)\end{array}$ & $\begin{array}{l}-3.28 \\
(1.56)\end{array}$ & $\begin{array}{l}30.6^{*} \\
(2.58)\end{array}$ & $\begin{array}{l}-5.35^{*} \\
(4.55)\end{array}$ & $\begin{array}{l}97.7 * \\
(2.64)\end{array}$ & $\begin{array}{l}-2.71^{*} \\
(1.71)\end{array}$ & $\begin{array}{c}145^{*} \\
(2.02)\end{array}$ \\
\hline TV & $\begin{array}{c}-0.678 \\
(0.81)\end{array}$ & $\begin{array}{l}-0.0458 \\
(1.13)\end{array}$ & $\begin{array}{l}1.06 \\
(0.52)\end{array}$ & $\begin{array}{r}-17.6 \\
(1.51)\end{array}$ & $\begin{array}{l}5.00^{*} \\
(4.74)\end{array}$ & $\begin{array}{c}-49.2 \\
(1.38)\end{array}$ & $\begin{array}{l}0.216 \\
(0.15)\end{array}$ & $\begin{array}{l}23.3 \\
(0.33)\end{array}$ \\
\hline TIME & $\begin{array}{l}0.0506 \\
(0.99)\end{array}$ & $\begin{array}{l}0.00308 \\
(1.49)\end{array}$ & $\begin{array}{l}-0.258^{*} \\
(2.00)\end{array}$ & $\begin{array}{c}1.66^{*} \\
(2.25)\end{array}$ & $\begin{array}{l}-0.125^{*} \\
(2.13)\end{array}$ & $\begin{array}{c}0.991 \\
(0.46)\end{array}$ & $\begin{array}{l}-0.0265 \\
(0.32)\end{array}$ & $\begin{array}{c}1.56 \\
(0.35)\end{array}$ \\
\hline Constant & $\begin{array}{l}9.41^{*} \\
(1.96)\end{array}$ & $\begin{array}{c}1.21^{*} \\
(3.57)\end{array}$ & $\begin{array}{l}43.9 * \\
(3.70)\end{array}$ & $\begin{array}{l}245^{*} \\
(3.65)\end{array}$ & $\begin{array}{l}35.0^{*} \\
(4.09)\end{array}$ & $\begin{array}{l}398 * \\
(1.91)\end{array}$ & $\begin{array}{c}-10.6 \\
(0.78)\end{array}$ & $\begin{array}{l}3,510^{*} \\
(5.69)\end{array}$ \\
\hline $\begin{array}{l}\text { Adjusted } R^{2} \\
\text { No. of }\end{array}$ & .535 & .711 & .826 & .853 & .687 & .700 & .491 & .799 \\
\hline observations & 56 & 56 & 52 & 52 & 52 & 52 & 52 & 52 \\
\hline
\end{tabular}

NOTE: Absolute $t$ statistics appear in parentheses. HHI = Herfindahl-Hirschman Index.

*Significant at .10 level or better. 
effect, though, requires that NCAA members correctly anticipate the impact of scholarship limits. Regulations sometimes have unintended consequences or fail to achieve their goal. We examine the determinants of the vote to reduce the scholarship limit from 95 to 85 for direct evidence on the motive for scholarship limits. ${ }^{12}$

The NCAA often passes measures via roll-call votes, and these votes have been used to explore the cartel's motives (DeBrock \& Hendricks, 1990; Fleisher, Goff, \& Tollison, 1990). The vote at the NCAA's 1991 annual meeting was 59 to 43 in favor of lowering the limit. Seven conferences voted on the proposal, so 95 schools cast votes. We estimate the following probit model of the roll-call vote:

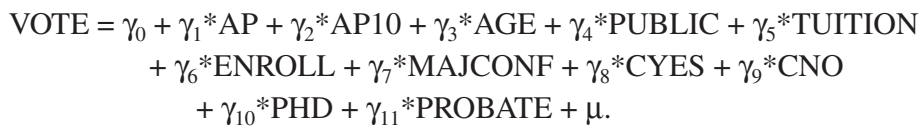

VOTE is a dummy variable that equals one for schools voting to reduce the limit. AP and AP10 measure performance in the final AP poll. We assign points for appearances on a descending basis; the team ranked 1st receives 20 points, the team ranked 2nd 19 points, and so on down to 1 point for the team ranked 20th. AP sums teams' scores over the entire period of the AP poll, 1936 to 1991, whereas AP10 sums teams' scores over the 10 seasons prior to the vote, 1982-1991. Positive signs for AP and AP10 indicate that traditional powers might have been trying to entrench themselves, whereas negative signs suggest that the have-nots were trying to level the playing field. We allow both historical and recent success to separately influence the vote. AGE is the age in years of the university in 1992. PUBLIC is a dummy variable that equals one for state and state-supported universities. Access to state funding for stadiums and facilities and legislative appropriations to cover a portion of the cost of education might produce different attitudes toward scholarship limits for public and private schools. TUITION is in-state tuition in thousands of dollars and proxies the cost to the school of scholarship (even if the economic cost of a student athlete is less than tuition) as well as the cost to players of walking on without a scholarship. The cost effect suggests a positive sign for this variable, whereas the walk-on effect predicts a negative sign for this variable. ENROLL is the school's total enrollment in the 1991-92 academic year in thousands of students. MAJCONF is a dummy variable that equals one if a school was a member of a major conference in 1992, which we define here as the Atlantic Coast, Big East, Big 8, Big 10, Pacific 10, Southeastern, and Southwest. ${ }^{13}$ Conferences share television and bowl revenues, so members of the major conferences could have different positions toward scholarship limits than independents or members of minor conferences. CYES and CNO are dummy variables that equal one for members of conferences that voted for and against the lower scholarship limit. If the conference votes represent the views of members, these variables should have positive and negative signs, respectively. Note that members did not vote as a block in line with their con- 
ference; Michigan and Tennessee, for example, voted for the lower limits, whereas the Big 10 and Southeastern Conference voted against. PHD is a dummy variable that equals one for doctoral-granting universities (a school must have a minimum number of Ph.D. programs across disciplines). Graduate education may be a competitor for football resources at doctoral-granting institutions. PROBATE is a dummy variable that equals one for schools on NCAA probation for football between 1953 and 1991. We employ Fleisher et al.'s (1992) list of schools on probation between 1953 and 1983, updated with our own search of NCAA records for 1984 to $1991 .{ }^{14}$ Past NCAA rules violations could affect a school's attitude toward stricter rules in the future.

We are most interested in whether past success affected voting. The mean value of AP for the schools voting yes was 105.4, whereas the mean for schools voting no was 105.1, so historical success would seem to be irrelevant. Schools voting yes did have slightly greater recent success; the mean of AP10 was 22.2 for schools voting yes and 18.3 for schools voting no. We estimated the full model with both AP and AP10 as independent variables, but both were insignificant. The two measures of success are highly correlated (correlation coefficient $=.77$ ), so we estimated the model with AP and AP10 separately. We present here the probit estimate of the model of voting with AP10 (absolute $t$ statistics in parentheses)

$$
\begin{aligned}
& \text { VOTE }=.965+.00940 * \mathrm{AP} 10+.00535 * \mathrm{AGE}-.206 * \mathrm{TUTION}+.00303 * \text { ENROLL (3) } \\
& \begin{array}{llll}
(0.67) \quad(1.76) \quad(1.18) \quad(1.69) & (0.15)
\end{array} \\
& -.700 * \text { MAJCONG + 1.31*CYES }-.692 * \mathrm{CNO}+1.77 * \mathrm{PHD}-.385 * \text { PROBATE } \\
& \text { (1.76) (2.66) (1.93) (2.45) }
\end{aligned}
$$

$N=95$, percentage of correct predictions $=74.7$.

The regression finds that recently successful teams were more likely to vote for the limits, consistent with the thesis that scholarship limits entrench incumbents. But the interpretation must be qualified because when the model was estimated with AP, AP was positive and insignificant (coefficient of $.00205, t$ statistic of 1.40). ${ }^{15}$ Conference votes for and against the measure are significant determinants of voting in the expected direction, and doctoral-granting institutions were more likely to support the lower limit. Members of major conferences, public universities, and schools with higher tuition were all significantly more likely to vote against the proposal. ENROLL, AGE, and PROBATE were all insignificant.

\section{CONCLUSIONS}

Conventional wisdom holds that parity is greater in college football today than ever before and that scholarship limits have fostered today's competitive balance. A variety of measures indicate that the stylized fact is false; indeed, several measures indicate that college football has been less balanced since the imposition of scholar- 
ship limits. Regression analysis of time series measures indicates that the relationship between scholarship limits and parity is complicated. Scholarship limits seem to have reduced within-year parity while increasing parity as measured with the AP Top 20. Only 4 out of 16 scholarship-limit coefficients were significantly consistent with greater parity, so again the conventional wisdom is without support. The effect of scholarship limits suggests they serve to limit resources spent on football. An examination of the NCAA vote reducing the scholarship limit to 85 finds that recent success on the field made schools more likely to vote for the lower limit, but success over the entire postwar period did not affect voting. These results support the interpretations that the limits were to protect incumbent football powers or perhaps to protect rents generated by amateur status; the interpretation that weaker schools voted to level the playing field is rejected.

Our results raise the question, Why do scholarship limits not produce greater parity? Three explanations seem possible: (a) Scholarship limits have not been enforced or have been evaded, (b) the current limit of 85 scholarships is too high for limits to weaken strong programs, or (c) limits negatively impact both strong and weak programs, leaving competitive balance unchanged. The NCAA can easily measure the number of scholarships awarded, and athletes with scholarships for other sports cannot play football, so lack of enforcement of the current limit seems inadequate. Our research does not allow us to discriminate between the other two explanations. Future research on this question might focus on the relative impact of nonscholarship, walk-on players. If traditional powers attract more and better walkons than also-rans, this would suggest that marginally lower scholarship limits will not increase parity and may even entrench incumbents.

\section{NOTES}

1. Scholarship limits were imposed in the 1970s before Title IX and gender equity became a concern in college athletics. Conceivably, repeal of scholarship limits today may have less effect on the number of scholarships than their imposition in 1977.

2. The tendency of people to overrate their relative ability also tends to help traditional powers in signing top high school players, many of whom will end up being reserves.

3. Nebraska, for instance, has a very successful walk-on tradition and has won at least nine games every year from 1968 to 2001.

4. The University of Pittsburgh in fact pursued this strategy under Johnny Majors in the 1970s; the university granted 83 scholarships in Majors's first recruiting class, a class that posted a 33-13-1 record and won the 1976 national championship (Byers, 1995, p. 228).

5. As Daly and Moore (1981) argue, teams may not consider the public good benefit of increased interest in the sport as a whole, and thus, players may move to the teams with the highest marginal private value but not the highest marginal value for the league as a whole.

6. Only a limit on the total number of scholarships would be necessary to reduce the total cost of college football, and thus, rent dissipation cannot explain the limit of 25 scholarships per year.

7. For cochamps we give each team a fractional title and allow fractional titles to sum to one in determining the number of different teams to win a title over a period. 
8. The war disrupted the normal conduct of the sport; teams of military personnel competed against college teams. Excluding the war years would leave only a few years of Associated Press (AP) rankings from the 1930s.

9. The conference champion variables for this comparison used the ACC, Big 10, Big 8/12, Pacific Coast, and SEC.

10. The time series conference champion variable drops the ACC, which did not form until 1953, and uses the Southwest Conference until the 1995 season, replaced then by the Big East.

11. Three other control variables were also included: PROP 48, a dummy variable equaling one for the years in which the NCAA's Proposition 48 academic eligibility requirements were in place for freshmen (1986-2001); NCAA, a dummy variable equaling one for the years prior to NCAA enforcement (1946-1951); and SPEND, real per capita aggregate state government spending. In no case were any of these variables significant, and so they are omitted in the specifications presented here.

12. No roll-call vote was recorded when the initial 95 -scholarship limit was adopted.

13. These were the same conferences used for our conference champion variable, except for the addition of the ACC. The champions of these conferences now receive automatic berths in the Bowl Championship Series, except that the Big 12 is the successor to the Big 8 and SWC. We include Penn State in the Big 10 even though it did not play football in the conference until 1993.

14. The penalties involved for schools on probation varied considerably, from public reprimands to the "death penalty" 1-year suspension of the program at Southern Methodist University. We excluded several schools from the NCAA's list where apparently no penalty was imposed. In total, 40 of the 95 schools in our roll call were on probation.

15. The coefficients on the other variables were very similar, with AP in place of AP10.

\section{REFERENCES}

Barro, R. J. (1996). Getting it right: Markets and choices in a free society. Cambridge, MA: MIT Press. Becker, G. S. (1987). The NCAA: A cartel in sheepskin clothing. Business Week, September 14, p. 24.

Bennett, R. W., \& Fizel, J. (1995). Telecast deregulation and competitive balance: Regarding NCAA Division I football. American Journal of Economics and Sociology, 54(2), 183-199.

Borland, M. V., Goff, B. L., \& Pulsinelli, R. W. (1992). College athletics: Financial burden or boon? Advances in the Economics of Sports, 1, 215-235.

Butler, M. R. (1995). Competitive balance in Major League Baseball. American Economist, 39(2), 4650.

Byers, W. (with Hammer, C.). (1995). Unsportsmanlike conduct: Exploiting college athletes. Ann Arbor: University of Michigan Press.

Coase, R. (1960). The problem of social cost. Journal of Law and Economics, 3, 1-44.

Daly, G., \& Moore, W. J. (1981). Externalities, property rights and the allocation of resources in Major League Baseball. Economic Inquiry, 19, 77-95.

DeBrock, L., \& Hendricks, W. (1997). Setting rules in the NCAA cartel. Advances in the Economics of Sport, 2, 179-201.

Eckard, E. W. (1998). The NCAA cartel and competitive balance in college football. Review of Industrial Organization, 13, 347-369.

Fizel, J., \& Bennett, R. W. (2001). College sports. In W. Adams \& J. Brock (Eds.), The structure of American industry (10th ed., pp. 323-350). Upper Saddle River, NJ: Prentice Hall.

Fleisher, A. A., III, Goff, B. L., Shughart, W. F., \& Tollison, R. D. (1988). Crime or punishment? Enforcement of the NCAA football cartel. Journal of Economic Behavior and Organization, 10, 433-451.

Fleisher, A. A., III, Goff, B. L., \& Tollison, R. D. (1990). NCAA voting on academic requirements: Public or private interest? In B. L. Goff \& R. D. Tollison (Eds.), Sportometrics (pp. 173-178). College Station: Texas A\&M University Press. 
Fleisher, A. A., III, Goff, B. L., \& Tollison, R. D. (1992). The National Collegiate Athletic Association. Chicago: University of Chicago Press.

Frank, R. H., \& Cook, P. J. (1995). The winner-take-all society. New York: Penguin Books.

Hylan, T. R., Lage, M. J., \& Treglia, M. (1996). The Coase theorem, free agency, and Major League Baseball: A panel study of pitcher mobility from 1961 to 1992. Southern Economic Journal, 62(4), 1029-1042.

McCormick, R. E., \& Tinsley, M. (1987). Academics versus athletics? Evidence from SAT scores. Journal of Political Economy, 95(5), 1103-1116.

McCormick, R. E., \& Tinsley, M. (1990). Athletics and academics: A model of university contributions. In B. L. Goff \& R. D. Tollison (Eds.), Sportometrics (pp. 193-204). College Station: Texas A\&M University Press.

Olson, M. (1965). The logic of collective action. Cambridge, MA: Harvard University Press.

Scully, G. (1989). The business of Major League Baseball. Chicago: University of Chicago Press.

Stassen, C. (2001). College football information. Available from http://www.stassen.com

Stigler, G. S. (1975). The citizen and the state: Essays on regulation. Chicago: University of Chicago Press.

Daniel Sutter earned his Ph.D. from George Mason University and is currently associate professor of economics at the University of Oklahoma. His research interests include sports economics, constitutional economics, the urban land assembly problem, the economics of the news media, and the economic impact of weather and natural hazards.

Stephen Winkler holds an MBA in finance from the University of Oklahoma. He is currently a financial analyst with the Oklahoma Publishing Company. 